\title{
MIR I IMPERIJA U NOVOM SVETSKOM PORETKU
}

\author{
Damjan Ćuprić \\ Univerzitet u Beogradu, Fakultet političkih nauka
}

$U$ radu se uticaj SAD-a na mir stavlja u kontekst imperije u novom svetskom poretku. Na prvom mestu, to predstavlja doprinos razumevanju mira nakon Hladnog rata. Drugo, pomaže pri sagledavanju struktura koje određuju delovanje SAD kao imperije i novih velikih sila, kako bi se utvrdilo kakav poredak uspostavljaju. Treće, omogućava uvid u praktične mehanizme vladanja SAD kao imperije. Četvrto, ovo pitanje ima izuzetan značaj u objašnjavanju savremenih pojava i procesa poput globalizacije, sve većeg broja međunarodnih organizacija, transnacionalnih institucija i transnacionalnih klasa, koje čine nadnacionalni svetski poredak - kao nove imperije. Zaključuje se da svetski mir ne zavisi od pojedinih država ili jedne države, već od promene imperijalne strukture nadnacionalnog poretka na globalnom nivou, konstituisanjem novog, humanijeg poretka.

Ključne reči: Mir, novi svetski poredak, imperija, SAD, globalizacija

straživanje započinjemo pitanjem: Da li je SAD kao imperija pretnja miru u novom svetskom poretku? Da bi se dao adekvatan odgovor, potrebno je definisati šta je novi svetski poredak, ispitati međusobnu uzročnu vezu u odnosu na mir između novog svetskog poretka, imperije i imperijalnog nadnacionalnog poretka, i najzad, dokazati da SAD jesu imperija u novom svetskom poretku. Odgovor na predloženo pitanje je istovremeno i početna hipoteza istraživanja - SAD kao imperija je u onolikoj meri pretnja miru u novom svetskom poretku koliko joj to omogućava jedna ista (imperijalna) uzročna logika koju poseduje struktura nadnacionalnog poretka.

Složeni aspekti teme istraživanja zahtevaju multidisciplinarni pristup, prevashodno sa stanovišta studija mira, bezbednosti i nauke o međunarodnim odnosima. $U$ istraživanju će se koristiti strukturna argumentacija. Prema Parsonsu, struktura se odnosi na sve stvari koje koristimo za objašnjenje neke pojedinačne akcije. ${ }^{1}$ Realizam je jedna od škola mišljenja koja sa svoje strane opisuje i objašnjava materijalne obrasce strukture. Strukturni realizam (neorealizam) pronalazi uzroke dešavanja u međunarodnim odnosima na nivou sistema, odnosno u međunarodnom sistemu, u njegovoj strukturi. ${ }^{2}$ Struktura među-

\footnotetext{
${ }^{1}$ Vid. Parsons, Craig, How to Map Arguments in Political Science, Oxford University Press, 2007, p. 49.

${ }^{2}$ Vid. Waltz, Kenneth N., Theory of International Politics, Reading, MA: Addison-Wesley, 1979, p. 78.
} 
narodnog sistema sastoji se od načina organizacije vlasti (anarhija ili hijerarhija) i raspodele moći u međunarodnom sistemu (unipolaran, bipolaran, multipolaran sistem).

Realisti racionalnog izbora smatraju da anarhija (koja je princip ili način organizacije vlasti u međunarodnoj politici, na nivou međunarodnog sistema) ne može da spreči da se u međunarodnim odnosima, naravno pod određenim okolnostima, pojave i neki oblici saradnje, kao i da međunarodne organizacije imaju jednu veoma važnu ulogu. U tom smislu će i strukturna paradigma pružiti argumente u objašnjenju načina na koji akteri reaguju (zavisna varijabla) na promenu strukture međunarodnog poretka (nezavisna varijabla), kao i u objašnjenju oblika njihove međusobne saradnje koja se odvija u „senci anarhije“ i „senci moći", kako to tvrdi realizam racionalnog izbora. $U$ istraživanju će se koristiti i normativna argumentacija, u delu koji se odnosi na distribuciju dobara i sredstava sa globalnog nivoa.

\section{Mir i novi svetski poredak}

Mir je najviša opšteljudska vrednost, ideal kome teži čovečanstvo. To bi značilo da nema oružanih sukoba, da su svi odnosi stabilni i zasnovani na pravednim principima koji su prihvatljivi za sve, da se svi sporovi rešavaju isključivo mirnim sredstvima, da je izvršeno globalno razoružanje i dr. Pod svetskim mirom se podrazumeva odsustvo svetskog rata, odnosno velikog rata u svetskim okvirima. $U$ užem smislu, svetski mir je naziv za povremene periode zatišja, vremenske intervale kada se u svetu nije ratovalo, kada nije bilo nijednog rata na planeti. U najužem značenju, pod svetskim mirom podrazumeva se stabilno stanje koje karakteriše potpuno odsustvo rata, realnost u kojoj je rat definitivno postao istorijska kategorija. Dakle, nešto što za sada realno ne postoji, nešto čemu se teži i nada. ${ }^{3}$

Norveški sociolog Johan Galtung i osnivač studija mira kao discipline, razlikuje negativni i pozitivni mir. Negativni mir predstavlja odsustvo direktnog, strukturnog i kulturnog nasilja, dok pozitivni mir definiše kao jedinstvo direktnog, strukturnog i kulturnog pozitivnog mira. ${ }^{4}$

Moguća početna tačka nastanka novog svetskog poretka odnosi se na pad Berlinskog zida, koji se dogodio 09. novembra 1989. godine. Zapadna i Istočna Nemačka su se ujedinile u jednu državu 03. oktobra 1990. godine. Sve ovo je pratio raspad Sovjetskog Saveza i njegova potpuna dezintegracija, koja se desila 25. decembra 1991. godine, čime se završila era bipolarnog međunarodnog sistema. Navedeni događaji su u toku 1991. godine bili praćeni završetkom japanskog ekonomskog uzleta i početkom ekonomskog uspona Kine, kao izvozno orijentisane ekonomije visoke stope rasta. U međuvremenu je usvojen Ugovor iz Mastrihta, 07. februara 1992. godine, čime je stvorena Evropska unija, umesto dotadašnje Evropske zajednice. SAD su u tom periodu predvodile međunarodnu koaliciju na Irak i na taj način ga primorale da se povuče iz Kuvajta. ${ }^{5}$

\footnotetext{
${ }^{3}$ Vid. Krivokapić, Boris, Mir i međunarodno pravo, Zbornik radova „Vladavina prava i pravna država u regionu“, Istočno Sarajevo, 2014, str. 928.

${ }^{4}$ Vid. Galtung, Johan, Mirnim sredstvima do mira - Mir i sukob, razvoj i civilizacija, Jugoistok 21 i Službeni glasnik, Beograd, 2009, str. 55.

${ }^{5}$ Vid. Friedman, George, Beyond the Post-Cold War World, Stratfor, (http://www.stratfor.com/weekly/beyondpost-cold-war-world), pristup: 02.11.2014.
} 
Dakle, tri ključne pojave karakterišu novi svetski poredak od kraja Hladnog rata: stvaranje različitih dodatnih komponenti američke moći; uspon Kine kao centra globalnog ekonomskog rasta jeftine radne snage; i stvaranje EU kao najveće integrativne ekonomske sile, pogotovo nakon pokretanja jedinstvene valute - evra, 01. januara 1999. godine.

Termin novi svetski poredak sadrži nekoliko sastavnih činilaca. To je poredak po kojem je funkcionisanje nekoliko jedinica ili država organizovano u skladu sa određenim zakonima, pravilima, vrednostima i okvirima; formulisan je u skladu sa opšte prihvaćenim rangiranjem sila i na taj način odražava prioritete i interese supersile koja dominira novim svetskim poretkom. Pridev svetski označava sve što se odnosi na svet i njegove dimenzije. To je moć koja sa sobom nosi odgovornost za donošenje globalne odluke ili preuzimanja odgovornosti za svetske poslove.

Teoretičar Dejvid Held smatra da se odrednica novi svetski poredak odnosi na bilo koji sistem koga čini interaktivni skup elemenata i uključuje upravljanje opštim principima, koji međusobno deluju u skladu sa posebnim ciljevima i zajedničkim interesima. ${ }^{6}$ Kostas Duzinas zastupa stav da je novi svetski poredak nastao posle propasti komunizma i definiše ga kao „istinski liberalni poredak“. Utemeljen je na pravnoj jednakosti, ustavnoj zaštiti individualnih prava, predstavničkoj vlasti i tržišnoj ekonomiji, zasnovanoj na pravu na privatno vlasništvo. ${ }^{7}$ Uprkos postojanju različitih pristupa u objašnjenju razvoja ovog poretka, svi potvrđuju postojanje novog svetskog poretka njegovim prisustvom u međunarodnoj diplomatiji, upravljanju svetskim krizama, globalizaciji ekonomije, širenju političkih, društvenih, kulturoloških i obrazovnih vrednosti, globalnog širenja demokratije i civilnog društva, kao i uspešne tehnološke revolucije u komunikacijama i informacijama.

Novi svetski poredak ima svoje osnove i temelje, koji su zasnovani na sledećim elementima: 1) Globalni konsenzus nad međunarodnim sporazumima, ugovorima i međunarodnom pravu; 2) Strateška ravnoteža vojnih snaga nasuprot ravnoteži interesa; 3) Interakcije i aktivnosti koji vode ka stvaranju globalnih organizacija, saveza i struktura, samim tim i ponašanja koje se menja u skladu sa međunarodnim okolnostima; 4) Promena ka globalizaciji na kulturnom, medijskom, trgovinskom i ekonomskom nivou; 5) Svetski trgovinski sistem, na čelu sa Svetskom trgovinskom organizacijom (STO); 6) Globalni finansijski sistem sačinjen od integrisane mreže nacionalnih centralnih banaka, regionalnih finansijskih institucija, kao što su Međunarodni monetarni fond (MMF), Svetska banka (SB) i globalno rasprostranjena valuta - američki dolar, kao jedinica u odnosu na koju se mere druge svetske valute. ${ }^{8}$

Globalizacija je razgradila sistem država funkcionalnom diferencijacijom strukture, menjajući time i sam organizacioni princip sistema. Nova struktura uključuje više nivoa, pa je možemo smatrati i višedimenzionalnom, za razliku od jednodimenzionalne anarhične strukture. Globalizacija je izmenila sredstva i kanale za vršenje i distribuciju moći izazvavši pojavu novih ekonomskih struktura i institucionalnih poredaka koji ujedno poseduju i normativni autoritet. Posednici nove normativnosti su privatni akteri (nedržavni akteri), kao i konglomerat aktera (transnacionalnih institucija i transnacionalnih klasa) koji čine nadnacionalni svetski poredak.

\footnotetext{
${ }^{6}$ Vid. Held, David, Democracy and the Global Order: From the Modern State to Cosmopolitan Governance (Stanford, CA: Stanford University Press, 1996), p. 11-13.

${ }^{7}$ Vid. Duzinas, Kostas, Ljudska prava i imperija - politička filozofija kosmopolitizma, Službeni glasnik, Albatros plus, 2010, str. 229.

${ }^{8}$ Vid. Slaughter, Anne-Marie, A New World Order (Princeton, NJ: Princeton University Press, 2004), p. 27-31.
} 
U svojoj suštini, novi svetski poredak se sastoji od skupa društvenih, ekonomskih, političkih, geografskih i kulturoloških realnosti, koje upravljaju odnosima unutar međunarodne zajednice i među njenim sastavnim činiocima - državama, ljudima, pojedincima i organizacijama civilnog društva. Ove realnosti deluju i podstaknute su od strane aktera i činilaca sistema, a posebno od strane jedinog pola koji dominira međunarodnom politikom i novim svetskim poretkom.

\section{Imperija u novom svetskom poretku}

Prema Majklu Hardu i Antoniju Negriju, imperija se pojavljuje kao pravna formacija sa osobenim nadnacionalnim ustavom i novim oblikom suvereniteta. ${ }^{9}$ Novi politički poredak globalizacije, tvrde Hard i Negri, valja posmatrati kao poredak bez granica i ograničenja. Ukazuju koliko se današnja imperija suštinski razlikuje od evropske imperijalističke dominacije i kapitalističke ekspanzije u prošlosti. Globalna imperija oslanja se na elemente američkog konstitucionalizma sa hibridnim identitetima i širenjem granica. ${ }^{10}$ Jedna od retkih dobrih osobina savremene imperije ogleda se u tome što je primerima kontakata i hibridizacije potkopala temelje nacionalne države, etniciteta, rase i naroda. Možda je, a u to veruju autori, savremena imperija omogućila stvaranje novih oblika transnacionalne solidarnosti koja će da porazi imperiju. „Moramo da prihvatimo taj izazov i da naučimo da mislimo globalno i delujemo globalno. Globalizaciji moramo da se suprotstavimo kontraglobalizacijom, imperiji kontra-imperijom. Kontra-imperija mora takođe da bude jedna nova globalna vizija, jedan nov način života u svetu.." ${ }^{11}$ lako tvrde da je sam koncept imperije uvek posvećen miru, praksa pokazuje suprotno. ${ }^{12}$

U knjizi Ljudska prava i imperija - politička filozofija kosmopolitizma, Kostas Duzinas postavlja centralno pitanje: Da li su prava delotvorno odbrambeno sredstvo protiv dominacije i tlačenja ili su ona samo ideološki instrument kojim se prikriva nastajanje imperije? Svaka država i imperija na svoj način interpretiraju moral i prava ljudi, koji odgovaraju njihovim prioritetima i interesima. Ukazuje na opasnost od moralizacije politike, tj. brisanja razlike između morala i prava, koja daje mogućnost pravu jačeg da pod plaštom uzvišenih moralnih ciljeva ostvaruje svoje uske nacionalne interese, učvršćujući novu konfiguraciju političkih, ekonomskih i vojnih snaga u svetu. Kostas Duzinas smatra da su osnovu za kodifikaciju ljudskih prava postavile velike države, posebno SAD. ${ }^{13}$ Društveni i politički sistemi postaju hegemonični, ukoliko svoje ideološke prioritete uzdignu na nivo univerzalnih principa i vrednosti. U novom svetskom poretku, zaštita ljudskih prava se postavlja iznad mira, a ne iznad državnog suvereniteta. Kada državni razlog ili rezon imperije progovore, pravo zaćuti. ${ }^{14}$

\footnotetext{
${ }^{9}$ Vid. Hardt, Michael and Negri, Antonio, Empire, (Cambridge, MA., Harvard University Press), 2000, p. 9.

${ }^{10} \mathrm{Ibid}$, p. 11.

${ }^{11}$ Vid. Hardt, Michael and Negri, Antonio, Empire, (Cambridge, MA., Harvard University Press), 2000, p. 169.

${ }^{12}$ Ibid, p. 170.

${ }^{13}$ Vid. Duzinas, Kostas, Ljudska prava i imperija - politička filozofija kosmopolitizma, Službeni glasnik, Albatros plus, 2010, str. 232.

${ }^{14} \mathrm{Ibid}$, str. 252.
} 


\section{SAD kao imperija}

Okončanjem bipolarne faze međunarodnih odnosa (završetkom Hladnog rata) došlo je do promene na nivou sistema, do nastanka unipolarnog momenta na čelu sa SAD, kao jedinom supersilom. Ova strukturna promena dovodi do novih izazova, rizika i pretnji (koji su višedimenzionalni, teško predvidivi i saznatljivi) i do pojave novog koncepta mira i bezbednosti (koji obuhvata, ne samo vojnu, već i političku, ekonomsku, socijalnu i ekološku dimenziju).

O SAD-u kao imperiji pisali su, između ostalih, Johan Galtung i Zbignjev Bžežinski. lako imaju različita viđenja tipa hegemonije i budućnosti SAD kao imperije, uočava se određeno preplitanje ovih autora u stavovima. Najznačajnija podudarnost odnosi se na unutrašnje razloge opadanja moći SAD. Galtung i Bžežinski u stvari obrazlažu različite varijante uticaja koju na SAD ima jedna ista uzročna logika koju poseduje struktura nadnacionalnog poretka.

Johan Galtung u svojoj knjizi Pad američke imperije - $i$ šta onda, naglašava da je imperija zasnovana na odnosima nejednake i neravnopravne razmene između Centra i Periferije, a ne na Periferiji geografije ili Centra političke zajednice. Imperiju definiše kao prekogranični sistem odnosa Centra i Periferije, u makro prostoru i vremenu, sa kulturom koja legitimiše strukturu nejednake razmene između Centra i Periferije: ekonomski, između eksploatatora i eksploatisanih, kao nejednakosti; vojno, između ubica i žrtvi, kao izvršenje; politički, između vladalaca i podanika, kao represija; kulturno, između otuđivača i otuđenih, kao uslovljavanje.

U globalnom sistemu država postoji Centar i Periferija. Unutar Centra, kao i unutar Periferije, takođe postoje centar i periferija. Smatra da imperije imaju različite profile. Ono što određuje američku imperiju, odnosi se na de facto ulogu Oružanih snaga SAD u obezbeđenju sigurnosti sveta, zarad američke ekonomije i otvorenosti ka širenju američke kulture. Drugim rečima, direktno nasilje se koristi za zaštitu strukturnog nasilja, koje je legitimizovano od strane kulturološkog nasilja. Pri tome se Centar odnosi na kontinentalni SAD, dok se Periferija odnosi na većinu sveta. Ključni stav koji zastupa Galtung, podrazumeva pad američke imperije kao neminovnost. Ali, pad američke imperije ne podrazumeva i pad američke Republike, koje Galtung suštinski razlikuje. Imperija je ta koja tlači, kontroliše i zbog koje dolazi do patnje periferije i izvan i unutar Republike.

Nakon kraja Hladnog rata, dolazi do povećanja prosečnog broja ratova na godišnjem nivou do dva puta, što je u skladu sa pretpostavkom da se ratovi uvećavaju kako imperija raste. Suština je u tome da su se SAD izgradile kao imperija, na osnovu ekonomske eksploatacije drugih država i ljudi, koristeći direktno i indirektno nasilje, pomoću različitih instrumenata podrške. Rezultat je međunarodna klasna struktura sa razlikama koje se uvećavaju između siromašnih i bogatih država, kao i siromašnih i bogatih ljudi. SAD kao imperija podržava one koji idu u korist povećanja njenog poslovanja i rasta, a radi protiv onih kojima je prioritet distribucija osnovnih potreba prema najugroženijima.

Galtung navodi postojanje određenih protivrečnosti u vezi SAD kao imperije. Njegovo predviđanje pada američke imperije zasnovao je na sinergiji 14 protivrečnosti, koje su postavljene u 2000. godini. Nejednaka razmena, podeljena na pet komponenti predsta-

\footnotetext{
${ }^{15}$ Vid. Galtung, Johan, The Fall of the U.S. Empire - And Then What?, TUP-TRANSCEND University Press, https://transcend.org/tms/?p=1422, 2009.
} 
vlja dubinsku protivrečnost imperije kao sistema. Nejednakost proističe iz nesputanog i neadekvatnog kapitalizma, iz tog razloga mu je potrebna vojna zaštita. Problem je u tome što nejednaka distribucija podrazumeva ubijanje, dominaciju i otuđenje. Pet dubinskih portivrečnosti (ekonomske, vojne, političke, kulturne i društvene) pretapaju se u 14 površinskih protivrečnosti:

- Ekonomske protivrečnosti odnose se na protivrečnosti između rasta i distribucije; između proizvodne i finansijske ekonomije; između proizvodnje, distribucije, potrošnje i prirode;

- Vojne protivrečnosti odnose se na protivrečnosti između terora SAD i terorizma; između SAD i saveznika; između hegemonije SAD u Evroaziji i trougla između Rusije, Indije i Kine; između NATO-a predvođen SAD-om i vojske EU;

- političke protivrečnosti: kritikuje misiju SAD-a, kao izabranog naroda; protivrečnosti koje se odnose između SAD i UN; između SAD i EU: bore se za pravoslavnu/islamsku podršku;

- kulturne protivrečnosti se odnose na veze između SAD judeo-hrišćanstva i islama; između SAD i starih civilizacija (kineske, indijske, mesopotamijske, itd.); između SAD i evropske kulturne elite - Francuske, Nemačke, itd.;

- društvene protivrečnosti se odnose na protivrečnosti između državno-korporativnih elita i radne klase nezaposlenih i radnika na ugovoru; između starijih i mladih generacija; između mita i realnosti. ${ }^{16}$

Imperija SAD, kao dinamička i funkcionišuća realnost, nije statična struktura, jer sa četrnaest protivrečnosti koje ima predstavlja veoma složen sistem. Ako SAD ne želi da se uruši kao imperija u narednih 20 godina, Galtung predlaže jednostavno rešenje: SAD treba da prekine ili umanji eksploataciju, ubijanje, vladanje, otuđivanje. Imperija se ne menja pobedom nad nekom stranom ili akterom, to može imperiju samo da učini imperijalnijom. To znači da se imperija može promeniti samo ako postane manje imperijalna. Ipak, smatra da je neminovan pad imperije i na kraju tog puta.

Zbignjev Bžežinski u knjizi Strateška vizija - Amerika i kriza globalne moći, svoju početnu premisu zasniva na stavu da moć SAD opada. Smatra da će još dugo godina SAD biti ključna, ali se sedište svetske moći pomera ka Aziji. Bžežinski kritikuje SAD što 1990. godine, u trenucima velikih promena na globalnom nivou, nije sebe učinila prihvatljivijom za ostatak sveta. U svetu vlada globalna borba između glavnih sila u svetskom poretku. Jedino jaka SAD može da spreči da rivalitet između novih sila (Kina, EU, Rusija, Indija) ne dobije paklenu erupciju. Zarad očuvanja mira i stabilnosti, to je jedan od glavnih razloga zašto je važno da SAD treba da bude i dalje jaka. Bžežinski kritikuje SAD što 1990. godine, u trenucima velikih promena na globalnom nivou, nije sebe učinila prihvatljivijom za ostatak sveta. Ističe sumnjičavost koju SAD ima i prema svojim saveznicima, a vidi i stanje nepoverenja između SAD i novih sila. ${ }^{17}$

Zaključuje da američka moć opada zbog unutrašnjih razloga u sferi ekonomije, duga, nejednakosti. Opominje da prvi put $u$ istoriji SAD, sadašnje generacije dece ne mogu da dostignu nivo socijalne pomoći u odnosu na prethodnu generaciju. Loše osnovno i srednje obrazovanje ima za posledicu neinformisanu javnost, a stanje infrastukture donosi lošu so-

\footnotetext{
${ }^{16}$ Vid. Galtung, Johan, The Fall of the U.S. Empire - And Then What?, TUP-TRANSCEND University Press, https://transcend.org/tms/?p=1422, 2009.

$17 \mathrm{https}$ ://orientalreview.org/wp-content/uploads/2012/12/Brzezinski-Zbigniew.-Strategic-Vision-America-andthe-Crisis-of-Global-Power.pdf, pristup: 30.11.2017.
} 
cijalnu mobilnost. Međutim, SAD i dalje poseduje jake strane, kao što su ekonomska moć, inovativni potencijal, počiva na resursima iz celog sveta (npr. ljudski resurs - svi stručnjaci sveta), uspešno asimiluje mladu migrantsku populaciju, itd. Bžežinski predlaže da se u 21. veku Zapad proširi i obuhvati Rusiju i Tursku. Evroazijski prostor, koji je oduvek imao ogroman geopolitički značaj, bio bi stavljen pod kontrolu kroz uspostavljanje saradnje sa Azijom. Bžežinski zaokružuje svoju viziju budućnosti sveta dajući ključnu ulogu SAD-u, koja jedina može da ujedini Zapad i spreči rivalitet između novih sila na Istoku, u Aziji. Da bi se to ostvarilo, SAD mora da izvrši neophodne unutrašnje reforme, pre svega u obrazovanju, ali i u svom spoljnjem delovanju, uspostavljanjem ravnoteže između sile i diplomatije. ${ }^{18}$

Herfrid Minkler u svojoj knjizi Imperije: logika vladavine svetom: od Starog Rima do Sjedinjenih Država, daje donekle drugačije viđenje glavnih karakteristika SAD kao imperije. Najpre ističe da je proces globalizacije toliko uznapredovao da su umesto „ekonomije topovnjača" na njeno mesto stupili Međunarodni monetarni fond i Svetska banka kao instrumenti globalne i finansijske politike koja se u velikoj meri poklapa sa američkim interesima. ${ }^{19}$ Smatra da će se američka imperija, oslonjena na privrednu globalizaciju, razvijati po modelu sledećeg ciklusa: globalizacija rađa failing states, jer ekonomski razvoj potkopava državnu vlast u ovim zemljama; onda diktatori preuzimaju kontrolu nad oblastima iz čijih rudnih bogatstava nameravaju da izvuku trajnu korist, a to opet ima za posledicu da se proces globalizacije na obodima imperije mora da osigurava preko vojnih jedinica i stvaranjem nacija. Postepeno, iz globalizacije tržišta nastaje intervencionistički imperijalizam ${ }^{20}$, odnosno niz ratova za uspostavljanje mira, iz kojih nastaje privremeni oblik svetske vladavine, ali ne i novi svetski poredak. ${ }^{21}$

Smatra da će SAD morati da privrednu integraciju i civilizacijsku privlačnost postepeno zamenjuju vojnom silom, odnosno moraće da soft power pretvaraju u hard power. ${ }^{22}$ Zaključuje da će američki ciklus da se završi u ratovima na periferiji, da će američka imperija propasti zbog nepovoljnog odnosa između problema koje treba rešavati i svojih ograničenih mogućnosti da pokrije troškove imperije. ${ }^{23}$

Mihail Ignjatijev govori o „novom obliku imperijalne vladavine u post-imperijalnom dobu“, koga obeležava zalaganje za ljudska prava i demokratiju, kao i uspostavljanje i osiguranje slobodnog tržišta. ${ }^{24}$ Za Andreja Baćevića, novina američke imperije sastoji se u

$18 \mathrm{https}$ ///orientalreview.org/wp-content/uploads/2012/12/Brzezinski-Zbigniew.-Strategic-Vision-America-andthe-Crisis-of-Global-Power.pdf, pristup: 30.11.2017.

${ }^{19}$ Vid. Minkler, Herfrid, Imperije: logika vladavine svetom: od Starog Rima do Sjedinjenih Država, Albatros plus i Službeni glasnik, Beograd, 2009, str. 202.

${ }^{20}$ Ovde treba navesti razliku između imperijalne i imperijalističke politike, gde se imperijalna politika uglavnom zanima za centar, a oblastima izvan imperije poklanja samo onoliko pažnje koliko je to neophodno. Imperijalistička politika je, po pravilu, opsednuta periferijom i ubeđena da se najveći izazovi nalaze na obodima, a ne u centru imperije. Ona se uvek više oslanja na vojna sredstva nego imperijalna politika, koja vojnoj moći pridaje samo relativan značaj, pored ekonomske, političke i kulturne moći.

${ }^{21}$ Vid. Minkler, Herfrid, Imperije: logika vladavine svetom: od Starog Rima do Sjedinjenih Država, Albatros plus i Službeni glasnik, Beograd, 2009, str. 202.

${ }^{22}$ Ibid, str. 203.

${ }^{23}$ Pitanje troškova, odnosno srednjoročnog odnosa između koristi i tereta imperijalne politike, kao i (ne)spremnosti američkih građana da podnose troškove imperije, predstavlja glavni problem američke imperije.

${ }^{24}$ Vid. Ignatieff, Michael, Empire Amerika?, in: Ulrich Speck/Natan Sznaider (Hg.), Empire Amerika. Perpsektiven einer neuen Weltordung, Munchen 2003, S. 30. 
odricanju od satelitskih država i u delovanju preko posredničkih institucija kao što su NATO, OUN, MMF i Svetska banka. ${ }^{25}$ Čarls Majer vidi specifičnost američke imperije u preplitanju privredne razmene i pružanja bezbednosnih garancija, ${ }^{26}$ dok za Dena Dinera američka imperija nije ništa drugo do političko i vojno obezbeđivanje svetskog tržišta, čije neprestano širenje ostavlja sve manje mesta za suverene države. ${ }^{27}$

Da bismo u potpunosti sagledali o kakvom se poretku radi, moramo se okrenuti istraživanju odnosa unutar ekonomskih, vojnih i političkih odlika aktera sistema. Ovo je neophodno iz razloga što se novi svetski poredak ne može odvojiti od rasporeda snaga u sistemu. Struktura novog svetskog poretka je hijerarhijska, sa SAD-om koji zauzima najvišu tačku, u skladu sa svojom sveobuhvatnom moći. Ta moć je izražena u vojnoj sili, koja premašuje bilo koju u dosadašnjoj istoriji ${ }^{28}$, jedinstvenoj kulturi i obrazovanju, najvećoj ekonomiji na svetu, neuporedivom tehnološkom vođstvu, globalnom prevlašću u energiji i saobraćaju, kao i u velikom doprinosu globalnoj inovaciji.

Sve ovo postalo je više nego očigledno nakon završetka ideološkog konflikta između komunizma i liberalnog kapitalizma, kao i dezintegracije Sovjetskog Saveza kao ekonomske i vojne sile. Jedina preostala supersila nameće svoju kontrolu vojno, ekonomski, tehnološki i politički, dok tržišna ekonomija i kapitalizam kontrolišu globalne ekonomske uslove. Postoji nekoliko indikatora koji potkrepljuju ovu tvrdnju. Pre svega, struktura moći u unipolarnom svetskom poretku jasno stoji u korist SAD i njene moći i uticaja u vojnoj, ekonomskoj, kulturološkoj, obrazovnoj, energetskoj i saobraćajnoj oblasti.

U 2012. godini, budžet odbrane SAD iznosio je 645,7 milijardi dolara, dok je zbir preostalih šest najvećih vojnih budžeta na svetu (EU, Kine, Rusije, Japana, Indije, Brazila) iznosio 575,6 milijardi dolara. ${ }^{29}$ Pored toga, bruto domaći proizvod SAD u 2012. godini je više od osam puta veći od BDP-a Indije, skoro sedam puta veći od Velike Britanije, pet puta veći od Nemačke, tri puta veći od Japana i više od duplo veći od Kine. ${ }^{30}$ U 2017. godini, ukupni vojni budžet SAD iznosi 793,7 milijardi dolara, od toga je osnovni budžet Ministarstva odbrane 574,5 milijardi dolara. ${ }^{31}$ Za 2018. fiskalnu godinu (koja obuhvata period od 1. oktobra 2017. godine do 30 . septembra 2018. godine), opredeljeno je 824,6 milijardi dolara. ${ }^{32}$ Time je vojni budžet SAD veći od zbira devet država sa najvećim izdva-

\footnotetext{
${ }^{25}$ Vid. Bacevich, Andrew J., Neus Rom, neues Jerusalem, in: Ulrich Speck/Natan Sznaider (Hg.), Empire Amerika. Perpsektiven einer neuen Weltordung, Munchen 2003, S. 171.

${ }^{26}$ Vid. Maier, Charles S., Die Grenzen des Empire, in: Ulrich Speck/Natan Sznaider (Hg.), Empire Amerika. Perpsektiven einer neuen Weltordung, Munchen 2003, S. 126.

${ }^{27}$ Vid. Diner, Dan, Das Prinzip Amerika, in: Ulrich Speck/Natan Sznaider (Hg.), Empire Amerika. Perpsektiven einer neuen Weltordung, Munchen 2003, S. 262.

${ }^{28}$ lako je udeo izdataka za odbranu SAD u 2016. godini iznosio 3,3\% BDP-a, što je prepolovljen iznos u poređenju sa vremenom Hladnog rata, to se ne može objasniti smanjivanjem troškova naoružanja u apsolutnim ciframa, već povoljnim privrednim razvojem SAD-a tokom 90-ih godina 20. veka, (https://data.worldbank.org/indicator/MS.MIL.XPND.GD.ZS, pristup 5. decembar 2017).

${ }^{29}$ Vid. Heeley, Laicie, US Defense Spending vs. Global Defense Spending, The Center of Arms Control and NonProliferation, (http://armscontrolcenter.org/issues/securityspending/articles/2012_topline_global_defense_spending), pristup: 02.11.2017.

${ }^{30}$ International Monetary Fund (IMF), World Economic Outlook Database, (http://www.imf.org/external/pubs/ft/weo/2013/01/weodata/index.aspx), pristup: 03.11.2017.

${ }^{31} \mathrm{http}: / /$ federal-budget.insidegov.com///120/2017-Estimate\#Revenues\&s=1cNiL, pristup: 30.11.2017.

${ }^{32}$ https://www.thebalance.com/u-s-military-budget-components-challenges-growth-3306320, pristup: 30.11.2017.
} 
janjima za budžet (Kina, Saudijska Arabija, Rusija, Ujedinjeno Kraljevstvo, Indija, Francuska, Japan, Nemačka, Južna Koreja). ${ }^{33}$

U pogledu inovacija, kreativnosti i konkurentnosti SAD su rangirane na prvom mestu. SAD doprinose za skoro četvrtinu od celokupnog iznosa budžeta Ujedinjenih nacija. ${ }^{34}$ Ono što SAD izdvaja kao supersilu u odnosu na druge sile, pored vojne, tehnološke i ekonomske prednosti, predstavlja stečeno iskustvo u upravljanju svetskim poslovima i međunarodnim krizama. Osim toga, SAD ima strateško planiranje budućeg pravca razvoja svetskih poslova, koje garantuje kontinuitet američke dominacije nad novim svetskim poretkom.

U oblasti obrazovanja, SAD ima vodeću ulogu po osnovu nekoliko ključnih indikatora. $\mathrm{Na}$ listi od 400 najboljih univerziteta na svetu u 2012. godini, nalazila su se 83 američka univerziteta. $^{35}$

U oblasti istraživanja, SAD je u samom vrhu liste po broju patenata, inovacija i izdvajanja za istraživanje i razvoj. ${ }^{36}$ Bruto društveni proizvod (BDP) SAD-a u 2012. godini iznosio je 15.685 triliona dolara. ${ }^{37} \cup 2016$. godini, BDP SAD-a bio je 18,57 triliona dolara, dok je BDP EU, na drugoj poziciji, bio 11,9 triliona dolara, a Kine 11,2 triliona dolara. ${ }^{38} \mathrm{U}$ 2016. godini, SAD su imale treći najveći BDP po stanovniku, sa 52.194 .90 dolara, nakon Švajcarske i Australije. ${ }^{39}$ Pored toga, američka ekonomija je najveća na svetu u smislu ponude novca. ${ }^{40}$

Sedište većine najvećih globalnih kompanija iz oblasti softvera i internet tehnologije (npr. Microsoft, Apple, Google) nalazi se na tlu SAD-a. Prva je na svetu po broju kompjutera na 100 stanovnika i druga posle Japana po broju korisnika interneta na 100 stanovnika. ${ }^{41}$ Po potrošnji energije, SAD zauzima prvo mesto. U poređenju sa drugim konkurentnim silama, SAD poseduje visoku sposobnost proizvodnje energije, po proizvodnji nafte je odmah iza Rusije i Saudijske Arabije, dok je po proizvodnji gasa na prvom mestu. ${ }^{42}$ Globalni napredak SAD-a omogućen je i posedovanjem strateških vazdušnih i morskih kapaciteta. SAD ima najveći broj aerodroma, kao i najdužu železničku i drumsku saobraćajnu infrastrukturu. ${ }^{43}$

\footnotetext{
$33 \mathrm{https}: / / w w w . u s n e w s . c o m / n e w s /$ best-countries/articles/2016-11-11/10-countries-with-the-largest-militarybudgets, pristup: 30.11 .2017 .

${ }^{34}$ UN Regular Budget (http://www.un.org), 05.11.2017.

${ }^{35}$ Central Intelligence Agency (CIA), Country Comparison: Education Expenditures, The World Factbook (Washington, DC: Central Intelligence Agency, 2013); (https://www.cia.gov/library/publications/the-worldfactbook/rankorder/2296rank.html); i The World Bank, Research and Development Expenditure (\% of GDP), (http://data.worldbank.org/indicator/GB.XPD.RSDV.GD.ZS) i (http://data.worldbank.org/products/wdi), pristup 03.11.2017.

${ }^{36}$ United Nations Development Program, Hyman Development Report, 2013, p. 198.

${ }^{37}$ International Monetary Fund (IMF), World Economic Outlook Database, op. cit.

${ }^{38} \mathrm{https} / / /$ tradingeconomics.com/united-states/gdp, pristup: 27.11.2017.

${ }^{39} \mathrm{https} / / /$ tradingeconomics.com/united-states/gdp-per-capita, pristup: 27.11.2017.

${ }^{40}$ United Nations Development Program, Hyman Development Report, 2013, p. 2.

${ }^{41}$ United Nations Development Program, Hyman Development Report, 2013, p. 198-201.

${ }^{42}$ International Monetary Fund (IMF), World Economic Outlook Database, op. cit.

${ }^{43}$ Central Intelligence Agency (CIA), The World Factbook (Washington, DC: Central Intelligence Agency, 2013), p. 12; (https://www.cia.gov/library/publications/the-world-factbook/geos/us.html), pristup: 05.11.2017.
} 


\section{Zaključak}

Anarhija ostaje suštinsko obeležje svetskog sistema i zato je SAD kao dominantna država u sistemu postala imperija, kao odgovor na anarhiju. Stoga možemo govoriti o američkoj hegemoniji kao ključnom faktoru oblikovanja svetskog poretka. Američka hegemonija proističe iz najjače ekonomske, vojne i ideološke pozicije u svetu, što dokazujemo uporednom analizom ekonomskih, vojnih, tehnoloških, energetskih, saobraćajnih, informacionih i obrazovnih pokazatelja.

Svetski poredak, kao poredak globalnog kapitalizma i svetskog društva, SAD uspostavlja preko vojnog intervencionizma, širenjem kulture i ideologije. Proces globalizacije je značajno doprineo uspostavljanju svetskog poretka, pa se on još naziva i amerikanizacijom, vesternizacijom, liberalizacijom ili demokratizacijom u skladu sa glavnim obeležjima američkog hegemonizma. ${ }^{44}$

$\mathrm{Na}$ izmaku druge decenije 21. veka, SAD su i dalje jedina supersila u novom svetskom poretku. lako i druge velike sile, kao što su Kina, Rusija i EU, pokušavaju da se suprotstave superiornoj poziciji SAD-a, teško je izmestiti ovaj pol svetske moći i preuzeti globalnu ulogu, pa čak i razviti bilo koju vrstu partnerstva, kako bi se predvodio novi svetski poredak. Razlog je u tome što su SAD nastavile da osiguravaju svoju prevlast u pogledu moći, nezavisnosti i uticaja koji imaju u novom svetskom poretku. Postojeća hijerarhija moći može da se promeni u slučaju da SAD odluči da ne zadržava svoju lidersku ulogu, ili ako se opredeli za uspostavljanje pristupa koji je manje konfrontirajući sa potencijalnim takmacima, pre svega Kinom, u potrazi za uspostavljanjem multipolarnog svetskog poretka.

SAD je svojom dominantnom vojnom, političkom, ekonomskom, kulturnom i ideološkom moći, uticajem i nezavisnošću, izgradila sebe kao imperiju unutar jednopolarnog svetskog poretka. SAD svoj odnos prema miru grade kroz interakciju i delovanje unutar nadnacionalnog poretka, čijem je stvaranju sama najviše doprinela. Stoga je SAD kao imperija u onolikoj meri pretnja miru koliko joj to omogućava imperijalna logika koju poseduje struktura nadnacionalnog poretka. Novi svetski poredak je u međuvremenu dobio svoje autonomne obrasce delovanja, koga određuju njegove norme, institucije, kao i konglomerati transnacionalnih aktera.

Ključni problem nije u SAD kao imperiji i njenom odnosu prema miru, već što je taj odnos određen imperijalnom strukturom nadnacionalnog poretka, u okviru čijih pravila, institucija, aktera i SAD funkcioniše kao imperija. Posmatra se globalni nivo analize, jer se problem u vezi sa stvaranjem uslova za održanje svetskog mira ne nalazi na nivou jedne države. Koliko god da je američka hegemonija bila bitna za uspostavljanje nadnacionalnog poretka, toliko on sada ne zavisi od pojedinih država, jer kreira transnacionalne institucije, norme i aktere, koji čine globalni poredak.

Nadnacionalni poredak je imperija, pod čijim uticajem deluje i SAD danas. U tom smislu, npr. ruska hegemonija ne bi donela suštinski bitnu promenu svetskog poretka, niti bi to uticalo na mir i stabilnost u svetu. I ruska hegemonija bi počivala na sličnim odnosima na kojima počiva i američka, a to su svetsko tržište, globalni kapitalizam i vojni intervencionizam.

Potrebno je da dođe do promene u strukturi svetskog poretka, koji je ustrojen na takav način da generiše nejednaku distribuciju sredstava i dobara ${ }^{45}$ i stvara neprijateljstva i

\footnotetext{
${ }^{44}$ Vid. Robinson, William, Promoting Polyarchy: Globalization, US Intervention, and Hegemony, Cambridge University Press, 1996, p. 36.

${ }^{45}$ Vid. Pogge, Thomas, Priorities of Global Justice, Metaphilosophy LLC and Blackwell Publishers Ltd. 2001, p. 16.
} 
nasilje, između bogatih i siromašnih, između razvijenih i nerazvijenih. Optimističko viđenje rešenja problema podrazumeva globalno konstituisanje novog poretka, koji za razliku od postojećeg, ne podleže podelama između Severa i Juga, Centra i Periferije, kao i Imperije i Republike (demokratije). Na globalnom nivou neće biti mira dok se ne promeni imperijalna struktura nadnacionalnog svetskog poretka, dok se njegove institucije, norme i akteri ne ustroje po meri stvarnih ljudskih potreba.

\section{Лumepamypa}

[1] Bacevich Andrew J., Neus Rom, neues Jerusalem, in: Ulrich Speck/Natan Sznaider (Hg.), Empire Amerika. Perpsektiven einer neuen Weltordung, Munchen 2003.

[2] Brzezinski Zbigniew, Strategic Vision - America and the Crisis of Global Power, Basic Books, New York, 2012.

[3] Diner Dan, Das Prinzip Amerika, in: Ulrich Speck/Natan Sznaider (Hg.), Empire Amerika. Perpsektiven einer neuen Weltordung, Munchen 2003.

[4] Галтунг Јохан, Мирним средствима до мира - Мир и сукоб, развој и цивилизација, Југоисток 21 и Службени гласник, Београд, 2009.

[5] Galtung Johan, Peace by Peaceful Means, London, SAGE, 1996.

[6] George Susan, The Corporate Utopian Dream, The WTO and Global War System, Seattle, November, 1999.

[7] Дузинас Костас, Људска права и империја - политичка филозофија космополитизма, Службени гласник, Албатрос плус, 2010.

[8] Ignatieff Michael, Empire Amerika?, in: Ulrich Speck/Natan Sznaider (Hg.), Empire Amerika. Perpsektiven einer neuen Weltordung, Munchen 2003.

[9] International Monetary Fund (IMF), World Economic Outlook Database, 2013.

[10] Кривокапић Борис, Мир и међународно право, Зборник радова „Владавина права и правна држава у региону“, Источно Сарајево, 2014.

[11] Maier Charles S., Die Grenzen des Empire, in: Ulrich Speck/Natan Sznaider (Hg.), Empire Amerika. Perpsektiven einer neuen Weltordung, Munchen 2003.

[12] Минклер Херфрид, Империје: логика владавине светом: од Cтарог Рима до Cједињених Држава, Албатрос плус и Службени гласник, Београд, 2009.

[13] Parsons Craig, How to Map Arguments in Political Science, Oxford University Press, 2007.

[14] Pogge Thomas, Priorities of Global Justice, Metaphilosophy LLC and Blackwell Publishers Ltd. 2001.

[15] Robinson William, Promoting Polyarchy: Globalization, US Intervention, and Hegemony, Cambridge University Press, 1996.

[16] United Nations Development Program, Hyman Development Report, 2013.

[17] Hardt Michael and Negri Antonio, Empire (Cambridge, MA., Harvard University Press), 2000.

[18] Harper John Lamberton, The Cold War, Oxford University Press, 2011.

[19] Held David, Democracy and the Global Order: From the Modern State to Cosmopolitan Governance (Stanford, CA: Stanford University Press, 1996).

[20] Slaughter Anne-Marie, A New World Order, Princeton, NJ: Princeton University Press, 2004.

[21] Waltz Kenneth N., Theory of International Politics, Reading, MA: Addison-Wesley, 1979. 


\section{Internet}

[1] Galtung Johan, The Fall of the U.S. Empire - And Then What?, TUP-TRANSCEND University Press, https://transcend.org/tms/?p=1422, 2009.

[2] International Monetary Fund (IMF), World Economic Outlook Database, (http://www.imf.org/external/pubs/ft/weo/2013/01/weodata/index.aspx), приступ: 03.11.2017.

[3] Heeley Laicie, US Defense Spending vs. Global Defense Spending, The Center of Arms Control and Non-Proliferation,

(http://armscontrolcenter.org/issues/securityspending/articles/2012_topline_global_defense_spendi ng), приступ 02.11.2017.

[4] The World Bank, Research and Development Expenditure (\% of GDP), (http://data.worldbank.org/indicator/GB.XPD.RSDV.GD.ZS) i

(http://data.worldbank.org/products/wdi), приступ 03.11.2017.

[5] UN Regular Budget (http://www.un.org), приступ: 05.11.2017.

[6] Central Intelligence Agency (CIA), Country Comparison: Education Expenditures, The World Factbook (Washington, DC: Central Intelligence Agency, 2013).

(https://www.cia.gov/library/publications/the-world-factbook/rankorder/2296rank.html), приступ: 05.11.2017.

[7] http://federal-budget.insidegov.com//120/2017-Estimate\#Revenues\&s=1cNiL, приступ: 30.11.2017.

[8] https://www.thebalance.com/u-s-military-budget-components-challenges-growth-3306320, приступ: 30.11.2017.

[9] https://www.usnews.com/news/best-countries/articles/2016-11-11/10-countries-with-thelargest-military-budgets, приступ: 30.11.2017.

[10] https://orientalreview.org/wp-content/uploads/2012/12/Brzezinski-Zbigniew.-StrategicVision-America-and-the-Crisis-of-Global-Power.pdf, приступ: 30.11.2017.

[11] https://data.worldbank.org/indicator/MS.MIL.XPND.GD.ZS, приступ 5. децембар 2017. 